\title{
The Way of Visual Persuasion In Chinese Propaganda Poster
}

\author{
Yuzhu Fu ${ }^{1}$, Cheng Yan ${ }^{2}$ \\ ${ }^{1}$ College of Communication and Art Design, University of Shanghai for Science and Technology, \\ shanghai, China \\ ${ }^{2}$ Luxun Academy of Fine Arts, Shenyang, China
}

Keywords: Public Art, Propaganda Posters, Farmers' Image, Visual Persuasion.

\begin{abstract}
As a form of public art, propaganda posters played a very important role in the field of public space in passing culture idea, guiding the social value and cultivating people aesthetic temperament and interests. Since The People's Republic of China was founded, a series of the typical theme and image had been created which played a positive role in society in order to unite the people, encourage the production. Based on farmers' image as the research object, this article aim to analysis how the propaganda posters as a public art achieve the purpose of the visual persuasion by shaping typical character image, sublimating daily life and highlighting ritualized perspective in the new period.
\end{abstract}

\section{Introduction}

Public art is a new concept introduced from the West to the Chinese art field in the late 20th century. As the "exotic", the connotation of public art has never been settled so far. Some scholars understand the public art from a cultural point of view as a cultural phenomenon. Some scholars research from the value of public art to start the interpretation of the concept of public art. Some scholars define public art from a number of practical functions perspectives. There are some scholars regard the core of public art is the public space rights and power issues. Regardless of the differences in these views, the researchers have reached a consensus on the richness, diversity, and understanding of the practical and social aspects of the connotation of public art. In this sense, public art as a public, unique art form, bear the transfer of cultural spirit, promote social values, and enhance the aesthetic taste and other important social responsibilities and mission. Roger William Brown, a famous social psychologist in the United States, points out that persuading efforts to persuade people by manipulating symbols to influence others' behavior is also a propaganda. [1] Public art is no doubt to shoulder the visual persuasion, and to guide people's social functions. Therefore, this paper takes the image of the peasants shaped in Chinese posters as an example to try to analyze the ways of realizing the public art form in the visual persuasion, and comment on the social effects and significance of the peasants' image in the poster.

\section{The first way of visual persuasion - To shape a typical example}

Shaping a typical model image is an effective means of visual persuasion. The so-called example is in the minds of the advanced model, highlight the character image, is a model, a typical and precedent people who has a prominent representative, persuasive and so on. The example has two basic values: model value and incentive value. The exemplary value of the example conveys a way of behaving that contains the inherent requirements of imitation of learning. When people see the example of the model image and demonstration behavior will produce the impulse to imitate.

The image of the peasantry in the new Chinese poster also contains a lot of example images, which, as a public symbol, influence the ideology and consciousness of all peasant groups through continuous communication. Farmers' example guides the peasants' ideology and behavior so that farmers can have a positive example of behavior in terms of words and deeds, ways of thinking and value judgments, so they are deeply educated. In fact, we can see all the peasant images that appear in the posters as an example of shape, because every image of the peasant is not directly or exactly equal 
to the real life of the farmers, but the artistic image that higher than life. The image of the peasants, shaped by the hands of the artists, embodies the lofty moral standards and values. The artist excludes the peasants' peasants' consciousness, such as selfishness, utilitarianism and so on, and highlights the characteristics of the peasants who are tall, sunny and ecstasy. As a special visual symbol, their appearance for the beginning of the founding of new China, called on farmers to actively participate in national agricultural production, the development of agricultural economy has an important role.

Shaping the typical peasant example is to influence and guide the majority of the population accounted for more than $80 \%$ of the population. Therefore, we can effectively promote the socialist political construction, economic construction, and cultural construction goals. The image of the peasantry modeled a bridge between the collective will and the peasantry, and produced a visual imagination through the bridge. Once this visual association is established, through all the media to promote the image of example as following. When the farmers image of the poster continue to repeat the positive health, optimistic and enterprising value judgments; continue to deep national ideas and moral norms specifically for the individual's image and behavior; continue to promote this visualization, infectivity of the education, the majority of ordinary farmers will believe in example, and in the process of imitation to complete the country, society and self understanding.

\section{The second way of visual persuasion - To sublimate day life}

From the sociological sense, life can be generally divided into two parts: daily life and non-daily life. Among them, the daily life is a personal family, natural community and other direct environment as the basic residence, aimed at maintaining the individual survival and reproduction of daily consumption activities, daily activities and daily activities of the general term. [2] It is a repetitive thinking and repetitive practice as the basic way of existence, by virtue of tradition, habits, experience and blood and natural emotions and other cultural factors to maintain the nature of the object-oriented domain. Therefore, daily life is narrow life world, which is mainly different from the various specialized and institutionalized areas formed by social differentiation. It is mainly characterized by sensibility, intuition, spontaneity, habit and repetition. Farmers or rural daily life refers to those activities that revolve around individuals and families. Because peasants are special groups built by the small peasant economic base, the daily life of the peasants is highly conservative and inert, and this repetitive daily life is clearly incompatible with full of creative and creative modern life. There is a big huge gap between this simply true farmers' daily life and the spirit that construct after the establishment of the new China. If the government wants to change the daily life of this form of life, it should be for the daily life of the village into a new content. Therefore, in the propaganda posters of new Chinese period, the farmers' daily life present a new form that all farmers' simple life concern with social construction, moral shaping, political philosophy and other forms of public discourse, and in further all the original life was given a special significance.

One of the strategies of sublimation of farmers' day life is to give new meanings and values to ordinary events and characters in order to convey the meaning of image symbols. This meaning is often in line with the mainstream spirit advocated by the nation, so that the viewer of the image, the recipient, through the image of the discourse to understand and absorb information, and then to convey the concept of acceptance and recognition. This kind of propaganda painting is usually describe in a way realistic, show a story or the scene of the incident, so that the appearance of farmers' daily life seems natural and not blunt, increasing highly true effect of the picture.

The daily life of the peasant image is closely linked to the individual and the country, and the individual's life is integrated with the great things of the country's construction. Posters of farmer's daily life become an important area for the spread of the collective will of the whole nation. Through the posters of daily life, the details of the behavior of the peasants' life are enlarged, the daily scope has been expanded, and the political grand theme has been integrated into the microscopic field of daily life. Poster is to use daily life behavior to guide the public opinion, regulate the function of social behavior, so as to achieve the role of ordinary people to persuade. 


\section{The third way of visual persuade - To highlight the ritualized perspective}

Ritual behavior is a special act that transcends everyday behavior, and it is often directly related to faith. Ritual action is different from the actual function of labor, attack or defense action, also different from the practical value of daily life action, but beyond the effectiveness and practical purpose of the abnormal behavior. The purpose of action is to express a certain emotion or the performance of a certain meaning. Rituals usually use symbolic ways to combine the real world with imagination. The ritualized expression embodied in the image of farmers is also accomplished by symbolism. In shaping of the farmers' image, the artist highlights the strength and beauty of the peasant's body, and is a kind of strengthened sense of power. Thus, by focusing on the strength of the body and strengthening the image of the peasantry to gain a sense of the whole body of power as a political theme of a body ritual. [3] Throughout the new China period posters, almost all young farmers are portrayed as images of heroic temperament. Both male and female are almost all taken the view of look up to appreciate in order to emphasizing the heroic stalwart image. This heroism is aimed at demonstrating the stalwart of workers, the image of tall and straight, and the high-handed emotions in production and reform, thus encouraging people to participate enthusiastically in social construction and agricultural production.

Ritual performance of the body reached its peak during the Cultural Revolution, the picture not only emphasizes the sense of power and heroism temperament, but also appears a trend that image and momentum are solidified. The peasants in the posters are always clenched, their arms are always held high, and their hands are always holding the quotations or writings that symbolize Chairman Mao. Farmers are always being with workers and soldiers; they are fighting and criticizing full of pride and passion. The recurrence of the ritual image reinforces the visual persuasion of the image, combining the political orientation with the aesthetic attitude and the fun at that time, and has had an important influence and effect on the people's thoughts and consciousness.

In addition to the rhythmic performance of the body, this feature is also reflected in the composition of the poster, which is the relationship between the leader and the peasantry. In the image, the farmers are basically around the side of Chairman Mao, listen to the President to preach or accompany the President to visit, between the chairman and the farmers presented a kind of intimate relationship. The embodiment and composition of this relationship is with some ritual symbolic approach. The circle is the only pattern in all geometries that is not divided by lines, and every point on the circumference is exactly the same, and perhaps it is a symbol of integrity and unity. [4] The circular surround ritual has a symbolic meaning that the center of the picture is generally the person or thing that represents the core, expressing a general understanding of all the people at that time, that is, around Chairman Mao, united around him, following the leaders to build the motherland. This ritual image shaped, expressing the people's reverence and love for the leaders, embodies the propaganda posters' important social significance as a form of public art.

\section{Conclusion}

After the founding of new China, in order to build a new national spirit, propaganda painting with visual images to create a socialist era of character "new peasant image". The farmers' images show a new image and aesthetic style. As an important kind of public art in that time, propaganda posters complete the mission of visual persuade to the farmers by three different ways. The first one is to shape a typical example, the second one is to sublimate farmers' day life and the third one is to highlight the ritualized perspective. Of course, it cannot be denied that the posters of the New China period were limited by the specific historical conditions, and there were limitations such as the singularity of the theme, the mode of the method, and the limited level of the aesthetic. However, as an art form of decanonization and anti-elitism, the image of the peasants in the posthumous period of the new China period has important positive significance in the large amount of public space. The posters quickly and effectively complete a series of important role through the visual persuasion, such 
as guide social spirit, improve public cultural quality and strengthen the national sense of cohesion and pride.

\section{Acknowledgements}

The work of this paper is supported by Humanities and Social Science Foundation of University of Shanghai for Science and Technology.

\section{References}

[1] Roger Brown, Words and Things: An Introduction to Language, The Free Press, (1958), P.300.

[2] Yi Junqing, Criticism of Modernization and Daily Life, Beijing: People's Publishing House, (2005), P. 31.

[3] Li Gongming, The Last Century Fifties and Sixties Agricultural Propaganda in The Harvest, Oriental Morning Post, June 18, (2014), 07th edition.

[4] Jack Tresidder, Shi Yi, Liu Yan translation. Symbolic Journey: Symbols and Their Meanings, Beijing: Central Compilation and Translation Press, (2001), P.148-149. 